\title{
7,11,13-Hexadecatrienal identified from female moths of the citrus leafminer as a new sex pheromone component: synthesis and field evaluation in Vietnam and Japan
}

\author{
Le Van VAnG, ${ }^{*}$ MD. Azharul Islam, Nguyen Duc Do, ${ }^{\dagger}$ Tran Van HaI,${ }^{\dagger}$ Shinji Koyano, ${ }^{\dagger \dagger}, * *$ \\ Yoshiki OKahana, ${ }^{\dagger \dagger}$ Nobuo OHBAYASHI, ${ }^{\dagger \dagger}$ Masanobu YAMAMOTO and Tetsu ANDO*** \\ Graduate School of Bio-Applications and Systems Engineering, Tokyo University of Agriculture and Technology, \\ Koganei, Tokyo 184-8588, Japan \\ ${ }^{\dagger}$ Department of Plant Protection, College of Agriculture, Cantho University, Can Tho City, Vietnam \\ ${ }^{\dagger}$ Ogasawara Subtropical Branch of Tokyo Metropolitan Agriculture and Forestry Research Center, \\ Chichijima, Ogasawara-mura, Tokyo 100-2101, Japan \\ ${ }^{\dagger \dagger \dagger}$ Entomological Laboratory, Faculty of Agriculture, Ehime University, \\ Matsuyama, 790-8566, Japan
}

(Received November 12, 2007; Accepted January 24, 2008)

\begin{abstract}
(7Z,11Z)-7,11-Hexadecadienal (Z7,Z11-16:Ald), which has been identified from female moths of the citrus leafminer (Phyllocnistis citrella, Lepidoptera: Gracillariidae), strongly attracts conspecific males in Japan. Recently, in addition to the dienyl aldehyde, a trienyl derivative, (7Z,11Z,13E)-7,11,13-hexadecatrienal (Z7,Z11,E13-16:Ald), was found as another sex pheromone component of females collected in Brazil and California. Thus, we synthesized Z7,Z11,E13-16:Ald and its isomer (Z7,E11,E13-16:Ald) to evaluate their effects on males inhabiting Asia. Starting from 1,7-heptanediol, two corresponding alcohols with trienyl structures were prepared by two applications of the Wittig-coupling reaction and then oxidized to yield objective aldehydes after separation by HPLC with an ODS column. In a citrus orchard in Can-Tho City, Vietnam, P. citrella males could not be caught by a lure baited only with Z7,Z11-16:Ald, but were successfully attracted with a 1:3 mixture of Z7,Z11-16:Ald and Z7,Z11,E13-16:Ald. On the other hand, in citrus orchards in Ogasawara (Bonin) Islands and Ehime Prefecture, Japan, neither trienals showed a synergistic effect on male capture by the dienal. Far from being reinforced, the attraction activity of the dienal was diminished by mixing in Z7,Z11,E13-16:Ald. These results indicated that the sex pheromone of the Vietnamese strain is similar to that of Brazilian and Californian strains, but the Japanese strain has established a different communication system from those of the foreign strains. (C) Pesticide Science Society of Japan
\end{abstract}

Keywords: Phyllocnistis citrella, lepidopteran sex pheromone, male attraction, field test, synthesis of trienyl aldehyde, chemical ecology.

\section{Introduction}

The citrus leafminer, Phyllocnistis citrella Stainton (Lepidoptera: Gracillariidae), is a harmful citrus pest. The larvae

* Present address: Can Tho University, Can Tho City, Vietnam.

** Present address: Tokyo Metropolitan Plant Protection Office, Fujimi 3-8-1, Tachikawa, Tokyo 190-0013, Japan.

*** To whom correspondence should be addressed.

E-mail: antetsu@cc.tuat.ac.jp

Published online March 25, 2008

(C) Pesticide Science Society of Japan mine into the epidermis of young leaves and shoots and induce a plant disease, citrus canker by Xanthomonas citri. In random screening tests of known pheromone components and their derivatives, $P$. citrella males were specifically attracted to (7Z,11Z)-7,11-hexadecadienal (Z7,Z11-16:Ald). ${ }^{1)}$ We then confirmed that virgin females actually secrete Z7,Z1116:Ald. ${ }^{2)}$ Analysis of the pheromone gland extract showed no other pheromonal components, indicating that this species utilizes a single-component pheromone for mating communication. The dienyl aldehyde, however, attracted no $P$. citrella males outside of Japan, and a trienyl derivative, (7Z,11Z,13E)-7,11,13-hexadecatrienal (Z7,Z11,E13-16:Ald), 
was recently identified as another sex pheromone component of females collected in Brazil and California. ${ }^{3,4)}$ The binary mixture of Z7,Z11-16:Ald and Z7,Z11,E13-16:Ald at a ratio of $1: 3$ strongly attracted the P. citrella males in those areas. Although some trienyl compounds have been identified, this identification is the first case of pheromone components with a 7,11,13-trienyl structure. $\left.{ }^{5,6}\right)$ We had an interest in the activity of the new compound against Asian strains, including Japanese ones, and synthesized Z7,Z11,E13-16:Ald and its geometrical isomer. This report presents their synthesis and field evaluation in citrus orchards in Japan and Vietnam.

\section{Materials and Methods}

\section{Analytical instruments}

${ }^{1} \mathrm{H}$ and ${ }^{13} \mathrm{C}$ NMR spectra were recorded by a Jeol Alpha 500 Fourier transform spectrometer (JEOL Ltd., Tokyo, Japan) at 500.2 and $125.7 \mathrm{MHz}$, respectively, for $\mathrm{CDCl}_{3}$ solutions containing TMS as an internal standard. ${ }^{1} \mathrm{H}-{ }^{1} \mathrm{H}$ COSY and HSQC spectra were also measured with the same spectrometer, using the usual pulse sequences and parameters. GC-MS was conducted in the EI mode with an HP 5973 mass spectrometer (Hewlett-Packard, Wilmington, DE, USA) equipped with a DB-23 capillary column $(0.25 \mathrm{~mm}$ i.d. $\times 30 \mathrm{~m}$, J \& W Scientific, CA, USA). The column temperature program was $50^{\circ} \mathrm{C}$ for $2 \mathrm{~min}, 10^{\circ} \mathrm{C} / \mathrm{min}$ to $160^{\circ} \mathrm{C}$, and $4^{\circ} \mathrm{C} / \mathrm{min}$ to $220^{\circ} \mathrm{C}$. The ionization voltage was $70 \mathrm{eV}$. High-resolution MS (HRMS) analysis was performed with a JMS-MS700V mass spectrometer (JEOL Ltd.). HPLC involved a pump system (Jasco PU980 liquid chromatograph, JASCO Corporation, Tokyo, Japan), an integrator (Chromatocorder 21J, System Instrument, Tokyo, Japan), a UV spectrometric detector (Jasco UV970) operated at $240 \mathrm{~nm}$, and an ODS column (Grand Pack ODS, $2.0 \mathrm{~cm}$ i.d. $\times 25 \mathrm{~cm}$; Senshukagaku, Tokyo, Japan). As the eluent, $12 \% \mathrm{H}_{2} \mathrm{O}$ in methanol was used at a flow rate of $4.5 \mathrm{ml} / \mathrm{min}$. IR spectra were recorded as thin films with a Jasco FT/IR-350 (JASCO Corporation).

\section{Chemicals}

Z7,Z11-16:Ald was synthesized by Swern oxidation of the alcohol, which was derived from the saponification of $(7 Z, 11 Z)$ 7,11-hexadecadienyl acetate supplied by Shin-Etsu Chemical Co., Ltd. (Tokyo, Japan). ${ }^{2)}$ Z7,Z11,E13-16:Ald and the (7Z,11E,13E)-isomer (Z7,E11,E13-16:Ald) were prepared by the following procedures (See Fig. 1).

\subsection{MOM ether of 7-bromoheptan-1-ol (2)}

A mixture of 1,7-heptanediol (1, 9.2 g, $70 \mathrm{mmol}), \mathrm{HBr}(48 \%$ in water, $11.8 \mathrm{~g}, 70 \mathrm{mmol})$, and toluene $(100 \mathrm{ml})$ was heated at $110^{\circ} \mathrm{C}$ overnight under refluxing and stirring conditions. After cooling, the reaction mixture was poured into water $(100 \mathrm{ml})$ and extracted with hexane. The hexane solution was washed with a saturated aqueous solution of $\mathrm{NaHCO}_{3}(100 \mathrm{ml})$ and chromatographed with a silica gel column to give 7-bromoheptan-1-ol (9.0 g, $46 \mathrm{mmol})$ in $66 \%$ yield. The produced bromohydrine was dissolved in dimethoxymethane $(200 \mathrm{ml})$, and $p$ - $\mathrm{TsOH}(600 \mathrm{mg})$ and $\mathrm{LiBr}(1.4 \mathrm{~g})$ were added to the solution. After stirring overnight at room temperature, the reaction mixture was poured into a saturated aqueous solution of $\mathrm{NaHCO}_{3}(200 \mathrm{ml})$ and extracted with hexane. Hexane and unreacted dimethoxymethane were removed by evaporation, and the residual materials were chromatographed on a silica gel column to give methoxymethyl (MOM) ether (2) (10.3 g, 43 mmol) in $93 \%$ yield. ${ }^{1} \mathrm{H}$ NMR $\delta: 1.40(6 \mathrm{H}, \mathrm{m}), 1.60(2 \mathrm{H}$, tt, $J=7,7 \mathrm{~Hz}), 1.86(2 \mathrm{H}, \mathrm{tt}, J=7,7 \mathrm{~Hz}), 3.36(3 \mathrm{H}, \mathrm{s}), 3.41(2 \mathrm{H}, \mathrm{t}$, $\left.J=7 \mathrm{~Hz}), 3.52(2 \mathrm{H}, \mathrm{t}, J=6.5 \mathrm{~Hz}), 4.62(2 \mathrm{H}, \mathrm{s}) .{ }^{7}\right){ }^{13} \mathrm{C}$ NMR $\delta$ : $26.0,28.1,28.6,29.6,32.7,33.9,55.1,67.7,96.4$. IR $\lambda_{\max }$ $\mathrm{cm}^{-1}: 2933,1464,1111,1047,920,644$. GC-MS $m / z$ (relative intensity): $t_{\mathrm{R}} 13.5 \mathrm{~min}, 239\left(2 \%,[\mathrm{M}-1]^{+}\right), 237(2 \%$, $\left.[\mathrm{M}-1]^{+}\right), 148(16 \%), 150(16 \%), 55(100 \%)$.

2.2. MOM ether of (Z)-4-undecene-1,11-diol (5)

A mixture of $2(2.4 \mathrm{~g}, 10 \mathrm{mmol})$ and triphenylphosphine $\left(\mathrm{Ph}_{3} \mathrm{P}, 2.9 \mathrm{~g}, 11 \mathrm{mmol}\right)$ was stirred in a three-necked flask and heated at $110^{\circ} \mathrm{C}$ overnight under $\mathrm{N}_{2}$ gas to give phosphonium salt of 2. The reaction mixture was cooled to $0^{\circ} \mathrm{C}$, and dry THF $(30 \mathrm{ml})$ was poured into the flask. $\mathrm{NaN}\left(\mathrm{SiMe}_{3}\right)_{2}(1.0 \mathrm{M}$ solution in THF, $11 \mathrm{ml}$ ) was then dropwisely added to the stirred solution under $\mathrm{N}_{2}$ gas to give ylide (3). After $30 \mathrm{~min}$ stirring in an ice bath, THP ether of 4-hydroxybutanal (2.1 g, $12 \mathrm{mmol}$ ), which was prepared from 1,4-butanediol by half THP protection and subsequent Swern oxidation, and dissolved in dry THF $(5 \mathrm{ml})$, was added to the mixture to be coupled with 3 . The reaction mixture was stirred for $1 \mathrm{hr}$ at room temperature after removing the ice bath, poured into water, and then extracted with hexane. The hexane extract was successively washed with $1.0 \mathrm{~N} \mathrm{HCl}$ and a saturated aqueous solution of $\mathrm{NaHCO}_{3}$, and chromatographed with a silica gel column to give (Z)-4-undecene-1,11-diol protected by two ether linkages $(4,1.7 \mathrm{~g}, 5.4 \mathrm{mmol})$ in $54 \%$ yield from 3 . The ether (4) was dissolved in EtOH (30 ml), mixed with $p$ - $\mathrm{TsOH}(100$ $\mathrm{mg}$ ), and heated at $50^{\circ} \mathrm{C}$. After stirring for $1 \mathrm{hr}$, the reaction mixture was poured into water $(100 \mathrm{ml})$, extracted with hexane, and washed with a saturated aqueous solution of $\mathrm{NaHCO}_{3}$. Since GC-MS analysis indicated a minor product with an $(E)$-double bond (about 7\%, $t_{\mathrm{R}} 20.4$ and $20.9 \mathrm{~min}$ ), the hexane extract was chromatographed using an $\mathrm{AgNO}_{3}$-silica gel column, and MOM ether of $(Z)$-4-undecene-1,11-diol $(\mathbf{5}, 900 \mathrm{mg}, 3.9 \mathrm{mmol})$ was obtained in $72 \%$ yield. ${ }^{1} \mathrm{H}$ NMR $\delta$ : $1.35(6 \mathrm{H}$, broad s), $1.65(4 \mathrm{H}, \mathrm{m}), 2.04(2 \mathrm{H}, \mathrm{m}), 2.12(2 \mathrm{H}, \mathrm{m})$, $3.36(3 \mathrm{H}, \mathrm{s}), 3.52(2 \mathrm{H}, \mathrm{t}, J=6.5 \mathrm{~Hz}), 3.64(2 \mathrm{H}, \mathrm{t}, J=6.5 \mathrm{~Hz})$, $4.62(2 \mathrm{H}, \mathrm{s}), 5.38(2 \mathrm{H}, \mathrm{m}) .{ }^{13} \mathrm{C}$ NMR $\delta: 23.6,26.1,27.1,29.0$, 29.6, 29.7, 32.7, 55.1, 62.9, 67.8, 96.4, 129.0, 130.6. IR $\lambda_{\max }$ $\mathrm{cm}^{-1}: 3429,2929,1460,1115,10455$. GC-MS $m / z$ (relative intensity): two peaks, $t_{\mathrm{R}} 20.5 \mathrm{~min}, 239\left(1 \%,[\mathrm{M}-1]^{+}\right), 198$ $(5 \%), 81(100 \%), t_{\mathrm{R}} 21.0 \mathrm{~min}, 239\left(0.5 \%,[\mathrm{M}-1]^{+}\right), 198$ (2\%), $81(52 \%), 59$ (100\%).

\subsection{MOM ether of 11-iodo-(Z)-7-undecen-1-ol (6)}

A mixture of $\mathrm{Ph}_{3} \mathrm{P}(1.2 \mathrm{~g}, 4.7 \mathrm{mmol})$, imidazole $(320 \mathrm{mg}, 4.7$ mmol), dry ether $(15 \mathrm{ml})$, and $\mathrm{CH}_{3} \mathrm{CN}(5 \mathrm{ml})$ was stirred at $0^{\circ} \mathrm{C}$, and $\mathrm{I}_{2}(1.2 \mathrm{~g}, 4.7 \mathrm{mmol})$ was added to the mixture in 
steps. After stirring at $0^{\circ} \mathrm{C}$ for $15 \mathrm{~min}$ and at room temperature for $15 \mathrm{~min}$, the mixture was dropwisely mixed with a hydroxyl compound $(\mathbf{5}, 900 \mathrm{mg}, 3.9 \mathrm{mmol})$ at $0^{\circ} \mathrm{C}$, continuously stirred at $0^{\circ} \mathrm{C}$ for $15 \mathrm{~min}$ and at room temperature for $1 \mathrm{hr}$, and poured into a $10 \% \mathrm{Na}_{2} \mathrm{~S}_{2} \mathrm{O}_{3}$ solution $(100 \mathrm{ml})$. The reaction mixture was extracted with hexane, washed with water, and chromatographed with a silica gel column to give iodide (6, $710 \mathrm{mg}, 2.1 \mathrm{mmol})$ in $54 \%$ yield. ${ }^{1} \mathrm{H}$ NMR $\delta$ : $1.35(6 \mathrm{H}$, broad s), $1.59(2 \mathrm{H}, \mathrm{m}), 1.87(2 \mathrm{H}, \mathrm{tt}, J=7,7 \mathrm{~Hz}), 2.06(2 \mathrm{H}, \mathrm{dt}, J=7$, $7 \mathrm{~Hz}), 2.14(2 \mathrm{H}, \mathrm{dt}, J=7,7 \mathrm{~Hz}), 3.19(2 \mathrm{H}, \mathrm{t}, J=7 \mathrm{~Hz}), 3.36$ $(3 \mathrm{H}, \mathrm{s}), 3.52(2 \mathrm{H}, \mathrm{m}), 4.62(2 \mathrm{H}, \mathrm{s}), 5.29(1 \mathrm{H}, \mathrm{m}), 5.43(1 \mathrm{H}$, m). ${ }^{13} \mathrm{C}$ NMR $\delta: 6.6,26.1,27.3,27.9,29.1,29.67,29.71$, $33.4,55.1,67.8,96.4,127.3,131.7$. IR $\lambda_{\max } \mathrm{cm}^{-1}: 2856$, $1454,1115,1043,731$. GC-MS $m / z$ (relative intensity): two peaks, $t_{\mathrm{R}} 20.8 \mathrm{~min}, 340\left(1 \%,[\mathrm{M}-1]^{+}\right), 308(2 \%), 81(100 \%)$, $t_{\mathrm{R}} 21.3 \min , 339\left(1 \%,[\mathrm{M}-1]^{+}\right), 308(0.5 \%), 81(35 \%), 59$ $(100 \%)$.

2.4. (7Z,11Z,13E)- and $(7 Z, 11 E, 13 E)$-Isomers of 7,11,13hexadecatrien-1-ol

With similar procedures to those used for the conversion of bromide (2) to a monoenyl compound (4), iodide (6) was converted into a trienyl compound. Namely, 6 (710 mg, 2.1 mmol) was treated with $\mathrm{Ph}_{3} \mathrm{P}(600 \mathrm{mg}, 2.3 \mathrm{mmol})$ to give a phosphonium salt, which was converted to ylide (7) by $\mathrm{NaN}\left(\mathrm{SiMe}_{3}\right)_{2}(1.0 \mathrm{M}$ solution in THF, $2.3 \mathrm{ml})$ and coupled with $(E)$-2-pentenal $(190 \mathrm{mg}, 2.3 \mathrm{mmol})$ to give MOM ether of 7,11,13-hexadecatrien-1-ol (260 mg, $0.93 \mathrm{mmol})$ in $44 \%$ yield from 6. The MOM ether was dissolved in methanol (7 $\mathrm{ml})$ and treated with $\mathrm{HCl}(4.0 \mathrm{~N}$ solution in dioxane, $1 \mathrm{ml})$ at room temperature overnight. The reaction mixture was poured into water $(50 \mathrm{ml})$ and extracted with hexane. The hexane extract was washed with a saturated aqueous solution of $\mathrm{NaHCO}_{3}$ and chromatographed with a silica gel column to give a mixture of Z7,Z11,E13-16:OH and Z7,E11,E13-16:OH $(190 \mathrm{mg}, 0.81 \mathrm{mmol})$ in $87 \%$ yield. The mixing ratio of the two geometrical isomers was about $2: 1$, and an aliquot of the mixture was supplied to preparative HPLC with an ODS column to separate the isomers $\left(\mathrm{Z} 7, \mathrm{Z} 11, \mathrm{E} 13-16: \mathrm{OH} t_{\mathrm{R}} 32.5 \mathrm{~min}\right.$, and Z7,E11,E13-16:OH $\left.t_{\mathrm{R}} 34.8 \mathrm{~min}\right) . \mathrm{Z7,Z11,E13-16:OH},{ }^{1} \mathrm{H}$ NMR $\delta$ : $1.02(3 \mathrm{H}, \mathrm{t}, J=7.5 \mathrm{~Hz}), 1.35(6 \mathrm{H}$, broad s), $1.55(2 \mathrm{H}$, $\mathrm{m}), 2.04(2 \mathrm{H}, \mathrm{m}), 2.12(4 \mathrm{H}, \mathrm{m}), 2.22(2 \mathrm{H}, \mathrm{dt}, J=7,7 \mathrm{~Hz})$, $3.64(2 \mathrm{H}, \mathrm{t}, J=6.5 \mathrm{~Hz}), 5.31(1 \mathrm{H}, \mathrm{dt}, J=11,7 \mathrm{~Hz}, \mathrm{H}-11), 5.38$ $(2 \mathrm{H}, \mathrm{m}, \mathrm{H}-7,8), 5.71(1 \mathrm{H}, \mathrm{dt}, J=15,6.5 \mathrm{~Hz}, \mathrm{H}-14), 5.97(1 \mathrm{H}$, dd, $J=11,11 \mathrm{~Hz}, \mathrm{H}-12), 6.30(1 \mathrm{H}, \mathrm{dd}, J=15,11 \mathrm{~Hz}, \mathrm{H}-13)$. GC-MS $m / z$ (relative intensity): $t_{\mathrm{R}} 21.06 \mathrm{~min}, 236\left(5 \%, \mathrm{M}^{+}\right)$, $135(5 \%), 95(100 \%)$. HRMS $m / z\left(\mathrm{M}^{+}\right)$: calcd. for $\mathrm{C}_{16} \mathrm{H}_{28} \mathrm{O}$ : 236.2140, found: 236.2113 . Z7,E11,E13-16:OH, ${ }^{1} \mathrm{H}$ NMR $\delta$ : $1.00(3 \mathrm{H}, \mathrm{t}, J=7.5 \mathrm{~Hz}), 1.34(6 \mathrm{H}$, broad s$), 1.56(2 \mathrm{H}, \mathrm{m}), 2.05$ $(4 \mathrm{H}, \mathrm{m}), 2.10(4 \mathrm{H}, \mathrm{m}), 3.64(2 \mathrm{H}, \mathrm{t}, J=6.5 \mathrm{~Hz}), 5.37(2 \mathrm{H}, \mathrm{m}$, H-7, 8), 5.61 (2H, m, H-11, 14), 6.01 (2H, m, H-12, 13). IR $\lambda_{\max } \mathrm{cm}^{-1}: 3338,2927,2856,1458,1057,980,725$. GC-MS $\mathrm{m} / \mathrm{z}$ (relative intensity): $t_{\mathrm{R}} 21.21 \mathrm{~min}, 236\left(5 \%, \mathrm{M}^{+}\right), 135$ (5\%), 95 (100\%). HRMS $\mathrm{m} / z\left(\mathrm{M}^{+}\right)$: calcd. for $\mathrm{C}_{16} \mathrm{H}_{28} \mathrm{O}$ : 236.2140, found: 236.2096 .

\subsection{Z7,Z11,E13-16:Ald and Z7,E11,E13-16:Ald}

Pyridinium chlorochromate (PCC, $40 \mathrm{mg}$ ) was added into a stirred $\mathrm{CH}_{2} \mathrm{Cl}_{2}$ solution $(10 \mathrm{ml})$ of $\mathrm{Z7,Z11,E13-16:OH} \mathrm{(30}$ $\mathrm{mg}, 0.13 \mathrm{mmol}$ ) by bits at room temperature. After stirring for $4 \mathrm{hr}$, the reaction mixture was poured into hexane $(50 \mathrm{ml})$, and dark precipitations were removed by filtration. After evaporation of the organic solvents, residual materials were purified by preparative TLC with a silica gel plate to give Z7,Z11,E13-16:Ald (19 mg, $0.081 \mathrm{mmol}$ ) in 62\% yield.

In the same manner, Z7,E11,E13-16:OH (20 mg, $0.085 \mathrm{mmol}$ ) was oxidized to Z7,E11,E13-16:Ald (12 mg, $0.051 \mathrm{mmol}$ ) in ca. 60\% yield. Z7,Z11,E13-16:Ald, ${ }^{1} \mathrm{H}$ NMR $\delta$ : 1.02 (3H, t, $J=7.5 \mathrm{~Hz}), 1.35(2 \mathrm{H}, \mathrm{m}), 1.64(2 \mathrm{H}, \mathrm{tt}, J=7.5$, $7.5 \mathrm{~Hz}), 2.05(2 \mathrm{H}, \mathrm{m}), 2.12(4 \mathrm{H}, \mathrm{m}), 2.21(2 \mathrm{H}, \mathrm{dt}, J=7,7 \mathrm{~Hz})$, 2.42 ( $2 \mathrm{H}, \mathrm{td}, J=7.5,2 \mathrm{~Hz}), 5.30(1 \mathrm{H}, \mathrm{dt}, J=11,7 \mathrm{~Hz}, \mathrm{H}-11)$, 5.38 (2H, m, H-7, 8), 5.71 (1H, dt, $J=15,6.5 \mathrm{~Hz}, \mathrm{H}-14), 5.97$ $(1 \mathrm{H}, \mathrm{dd}, J=11,11 \mathrm{~Hz}, \mathrm{H}-12), 6.30(1 \mathrm{H}, \mathrm{dd}, J=15,11 \mathrm{~Hz}, \mathrm{H}-$ 13), $9.76(1 \mathrm{H}, \mathrm{t}, J=2 \mathrm{~Hz})$. GC-MS $\mathrm{m} / z$ (relative intensity): $t_{\mathrm{R}}$ $19.25 \mathrm{~min}, 234\left(3 \%, \mathrm{M}^{+}\right), 135$ (3\%), 95 (100\%). HRMS m/z $\left(\mathrm{M}^{+}\right)$: calcd. for $\mathrm{C}_{16} \mathrm{H}_{26} \mathrm{O}: 234.1984$, found: 234.1946 . Z7,E11,E13-16:Ald, ${ }^{1} \mathrm{H}$ NMR $\delta$ : 1.00 (3H, t, $\left.J=7.5 \mathrm{~Hz}\right), 1.35$ $(4 \mathrm{H}, \mathrm{m}), 1.63(2 \mathrm{H}, \mathrm{tt}, J=7.5,7.5 \mathrm{~Hz}), 2.04(4 \mathrm{H}, \mathrm{m}), 2.11(4 \mathrm{H}$, m), 2.43 (2H, td, $J=7.5,2 \mathrm{~Hz}), 5.37$ (2H, m, H-7, 8), 5.61 (2H, m, H-11, 14), 6.01 (2H, m, H-12, 13), 9.76 (1H, t, $J=2$ $\mathrm{Hz}$ ). GC-MS $m / z$ (relative intensity): $t_{\mathrm{R}} 19.39 \mathrm{~min}, 234$ (3\%, $\left.\mathrm{M}^{+}\right), 135$ (3\%), 95 (100\%). HRMS $m / z\left(\mathrm{M}^{+}\right)$: calcd. for $\mathrm{C}_{16} \mathrm{H}_{26} \mathrm{O}: 234.1984$, found: 234.1958.

\section{Field trapping of male moths}

Attraction of $P$. citrella males by synthetic lures was examined in citrus orchards in Can Tho City, Vietnam, from November 21, 2005, to March 12, 2006, Ogasawara (Bonin) Islands (Chichi-jima), Japan, from November 17, 2005, to April 5, 2006, and Ehime Prefecture (Matsuyama-shi), Japan, from September 8 to October 27, 2007. A rubber septum (white rubber, o.d. $8 \mathrm{~mm}$, Sigma-Aldrich, St. Louis, MO, USA) was used as a dispenser of synthetic aldehydes and placed at the center of a sticky board trap $(30 \times 27 \mathrm{~cm}$ bottom plate with a roof, Takeda Chem. Co., Tokyo, Japan), which was set at $1.2-1.6 \mathrm{~m}$ above the ground with at least $10 \mathrm{~m}$ intervals. The number of captured males was counted at least once a week.

\section{Results}

\section{Synthesis of trienyl aldehyde}

Two geometrical isomers of 7,11,13-hexadecatrienal (Z7,Z11,E13-16:Ald and Z7,E11,E13-16:Ald) were synthesized starting from 1,7-heptanediol (1), as shown in Fig. 1. The $\mathrm{C}_{7}$ diol (1) was converted into MOM ether of 7-bromoheptan-1-ol (2) by half-bromination and subsequent MOM protection. The ylide (3), which was prepared from the bromide (2) by treatment with $\mathrm{Ph}_{3} \mathrm{P}$ and $\mathrm{NaN}\left(\mathrm{SiMe}_{3}\right)_{2}$, was coupled with an aldehyde derived from a $\mathrm{C}_{4}$ diol to yield a $\mathrm{C}_{11}$ monoenyl compound (4). Since a small amount of the corresponding $(E)$-isomer was detected in the crude product, the 

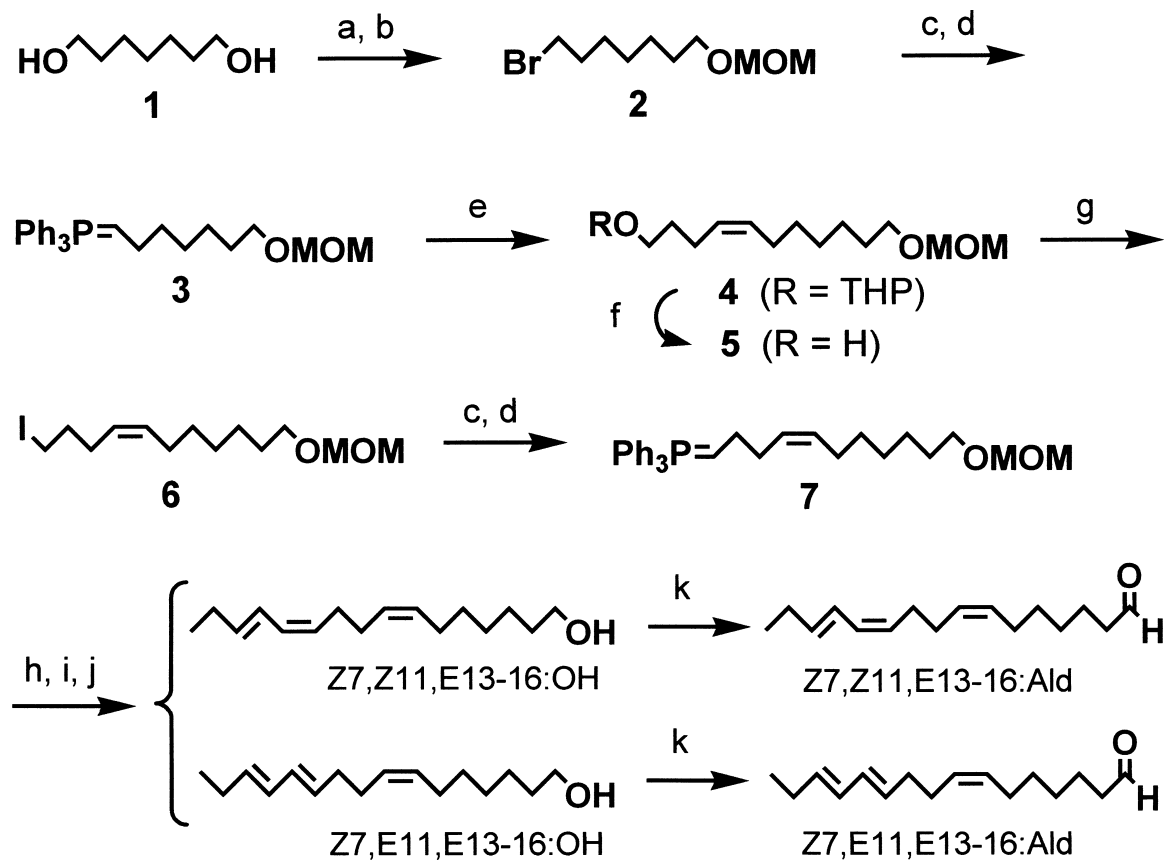

Fig. 1. Synthetic route to $(7 Z, 11 Z, 13 E)-7,11,13$-hexadecatrienal (Z7,Z11,E13-16:Ald) and its (7Z,11E,13E)-isomer (Z7,E11,E13-16:Ald). a, $\mathrm{HBr} /$ toluene; b, dimethoxymethane/ $p$-TsOH/LiBr; c, $\mathrm{Ph}_{3} \mathrm{P}$; d, NaN( $\left.\mathrm{SiMe}_{3}\right)_{2} / \mathrm{THF}$; e, $\mathrm{CHO}\left(\mathrm{CH}_{2}\right)_{3} \mathrm{OTHP}$; f, $p$-TsOH/EtOH; g, I $\mathrm{I}_{2}-\mathrm{Ph}{ }_{3} \mathrm{P} / \mathrm{imida}-$ zole/ether- $\mathrm{CH}_{3} \mathrm{CN}$; h, (E)-2-pentenal; i, dry $\mathrm{HCl} / \mathrm{MeOH} ; \mathrm{j}$, $\mathrm{HPLC} ; \mathrm{k}, \mathrm{PCC} / \mathrm{CH}_{2} \mathrm{Cl}_{2}$.

(Z)-alkene (4) was purified with an $\mathrm{AgNO}_{3}$-silica gel column. In acidic EtOH, only the THP group of diether (4) was removed to prepare a monohydroxy compound (5), which was transformed to MOM ether of 11-iodo-(Z)-7-undecen-1-ol (6) by iodination. The ylide (7), which was prepared from the iodide (6) by treatment with $\mathrm{Ph}_{3} \mathrm{P}$ and $\mathrm{NaN}\left(\mathrm{SiMe}_{3}\right)_{2}$, was coupled with (E)-2-pentenal, and a 2:1 mixture of MOM ethers of Z7,Z11,E13-16:OH and Z7,E11,E13-16:OH was obtained. After deprotection with $\mathrm{HCl}$ in dry dioxane, HPLC separation, and PCC oxidation, Z7,Z11,E13-16:Ald and Z7,E11,E13-16:Ald with $>98 \%$ purity were obtained.

2. NMR analysis of the synthetic trienyl compounds Proton signal assignments of each trienyl compound were accomplished by a ${ }^{1} \mathrm{H}^{1} \mathrm{H}$ COSY experiment. Z7,Z11,E1316:OH and Z7,Z11,E13-16:Ald showed well-separated signals of four olefinic protons from 11- to 14-positions without overlapping the signals of other olefinic protons at 7- and 8-positions. The coupling constants between the protons at the 11 and 12-positions $(11 \mathrm{~Hz})$ and those at the 13- and 14-positions $(15 \mathrm{~Hz})$ indicated $11 Z$ and $13 E$ configurations, respectively. In the case of Z7,E11,E13-16:OH and Z7,E11,E13-16:Ald, proton signals at the 11- and 14-positions overlapped, and those at the 12- and 13-positions also overlapped. While the configurations of the conjugated double bonds could not be directly determined by the coupling constants, the signal pattern was similar to that of conjugated dienes with an $E, E$ configuration. $^{8)}$

Table 1 shows ${ }^{13} \mathrm{C}$ NMR assignments for the trienyl com- pounds, which were achieved by an HSQC experiment. The configurations of three double bonds are reflected on the chemical shifts of the allylic carbons. ${ }^{9)}(7 Z, 11 \mathrm{Z}, 13 E)$-Isomers showed three signals around 27-28 ppm (C-6, C-9, and C-10), and $(7 Z, 11 E, 13 E)$-isomers showed two signals at $\sim 27 \mathrm{ppm}$ (C-6 and C-9) and one signal at $\sim 33$ ppm (C-10). Since allylic carbons at a $(Z)$-isomer generally resonate at $\sim 5 \mathrm{ppm}-$ higher fields than those at an $(E)$-isomer, the above signals confirmed the configurations at the 7- and 11-positions. In addition, each synthetic trienyl compound showed another allylic carbon signal at $\sim 26 \mathrm{ppm}$ (C-15), indicating $13 E$ configuration. Compounds with a $13 Z$ configuration are expected to show the signal of $\mathrm{C}-15$ at $\sim 21 \mathrm{ppm}{ }^{9}{ }^{9}$ Furthermore, the olefinic carbon signals of the conjugated dienyl part revealed the configurations. Chemical shifts from C-11 to C-14 of each 7,11,13-hexadecatrienyl compound coincided well with those from C-7 to C-10 of 7,9-dodecadien-1-ol with the same conjugated dienyl structure as that shown in Table 1. Namely, the $(7 Z, 11 Z, 13 E)$-isomers and (7Z,9E)-7,9-dodecadien-1-ol showed four similar olefinic carbon signals, and the $(7 Z, 11 E, 13 E)$-isomers and $(7 E, 9 E)-7,9-$ dodecadien-1-ol showed similar signals.

\section{Field attraction in Vietnam}

The synthetic trienals were evaluated at a citrus orchard in Can Tho City, Vietnam, from 2005 to 2006. First, lures baited with a binary mixture of Z7,Z11-16:Ald and Z7,Z11,E1316 :Ald in a ratio of $3: 1,1: 1$, or $1: 3$ were examined in addition to their single component lures (Test I). Each sole alde- 
Table 1. ${ }^{13} \mathrm{C}$ NMR assignments for $(7 Z, 11 Z, 13 E)$ - and $(7 Z, 11 E, 13 E)-7,11,13$-hexadecatrienyl compounds (alcohols and aldehydes), comparing with the data of $(7 Z, 9 E)$ - and $(7 E, 9 E)$-7,9-dodecadien-1-ols

\begin{tabular}{|c|c|c|c|c|c|c|}
\hline \multirow{2}{*}{ Position $^{a)}$} & \multicolumn{2}{|c|}{ Z7,Z11,E13- } & \multirow{2}{*}{$\mathrm{Z7,E9-12: \textrm {OH } ^ { b ) }}$} & \multicolumn{2}{|c|}{ Z7,E11,E13- } & \multirow{2}{*}{$\mathrm{E} 7, \mathrm{E} 9-12: \mathrm{OH}^{b)}$} \\
\hline & $16: \mathrm{OH}$ & 16:Ald & & $16: \mathrm{OH}$ & 16:Ald & \\
\hline 1 & 63.0 & 202.8 & & 63.1 & 202.8 & \\
\hline 2 & 32.8 & 43.9 & & $32.78^{c)}$ & 43.9 & \\
\hline 3 & 25.6 & 22.0 & & $25.65^{d)}$ & 22.0 & \\
\hline 4 & $29.1^{c)}$ & 28.8 & & $29.1^{e)}$ & 28.8 & \\
\hline 5 & $29.7^{c)}$ & 29.4 & & $29.6^{e)}$ & 29.4 & \\
\hline 6 & 27.2 & 27.0 & & $27.18^{f)}$ & $27.2^{c)}$ & \\
\hline 7 & 129.1 & 129.2 & & 129.0 & 129.26 & \\
\hline 8 & 130.4 & 130.0 & & 130.3 & 129.9 & \\
\hline 9 & 27.4 & 27.4 & & $27.16^{f)}$ & $27.0^{c)}$ & \\
\hline $10(6)$ & 27.8 & 27.8 & 27.7 & $32.73^{c)}$ & 32.7 & 32.6 \\
\hline $11(7)$ & 129.3 & 129.3 & 129.9 & 131.7 & 131.6 & 132.2 \\
\hline $12(8)$ & 129.0 & 129.0 & 128.8 & 130.7 & 130.7 & 130.6 \\
\hline $13(9)$ & 124.6 & 124.6 & 124.8 & 129.3 & 129.27 & 129.5 \\
\hline $14(10)$ & 136.5 & 136.5 & 136.1 & 134.2 & 134.3 & 133.9 \\
\hline $15(11)$ & 25.9 & 25.9 & 25.9 & $25.60^{d)}$ & 25.6 & 25.6 \\
\hline $16(12)$ & 13.6 & 13.6 & 13.7 & 13.6 & 13.6 & 13.7 \\
\hline
\end{tabular}

${ }^{a)}$ From C-1- to C-16 of hexadecatrienyl compounds, and from C-6- to C-12 of dodecadien-1-ols. ${ }^{b)}$ See reference $8 .^{c-f)}$ Chemical shift values in each column may be reversed.

hyde scarcely showed attractive activity, but the $1: 3$ mixture, which is known as the optimum lure for Brazil and California strains, effectively attracted $P$. citrella males in Vietnam, as shown in Table 2. Next, the activity of Z7,Z11-16:Ald mixed with Z7,E11,E13-16:Ald was compared with that of the $1: 3$ mixture of Z7,Z11-16:Ald and Z7,Z11,E13-16:Ald (Test II). While the natural-type mixture attracted the $P$. citrella males, lures including Z7,E11,E13-16:Ald, a geometrical isomer of the pheromonal trienal, caught scarcely any males, as shown in Table 3. The unnatural isomer was not substituted for

Table 2. Attraction of Phylocnistic citrella males by lures baited with synthetic Z7,Z11-16:Ald and Z7,Z11,E13-16:Ald in citrus orchards in Vietnam and Japan (Test I)

\begin{tabular}{|c|c|c|c|c|}
\hline \multirow{2}{*}{\multicolumn{2}{|c|}{$\begin{array}{l}\text { Lure components } \\
\text { (mg/rubber septum) }\end{array}$}} & \multicolumn{3}{|c|}{ Captured males/trap/night } \\
\hline & & \multirow{2}{*}{$\begin{array}{c}\text { Vietnam } \\
\text { Can Tho City }{ }^{a, b)}\end{array}$} & \multicolumn{2}{|c|}{ Japan } \\
\hline Z7,Z11-16:Ald & Z7,Z11,E13-16:Ald & & Ogasawara Islands ${ }^{c)}$ & Matsuyama-shi ${ }^{b, d)}$ \\
\hline 0.20 & 0 & $0.1 \pm 0.1 \mathrm{c}$ & 28.0 & $7.7 \pm 2.3 \mathrm{a}$ \\
\hline 0.15 & 0.05 & $1.2 \pm 0.2 \mathrm{~b}, \mathrm{c}$ & 18.4 & $1.4 \pm 0.7 \mathrm{~b}, \mathrm{c}$ \\
\hline 0.10 & 0.10 & $11.1 \pm 2.2 \mathrm{a}$ & 11.2 & $1.7 \pm 1.7 \mathrm{~b}, \mathrm{c}$ \\
\hline 0.05 & 0.15 & $27.6 \pm 16.3 \mathrm{a}$ & 6.9 & $0.8 \pm 0.4 \mathrm{~b}, \mathrm{c}$ \\
\hline 0 & 0.20 & $3.1 \pm 2.0 \mathrm{~b}$ & 0.2 & $1.0 \pm 0.7 \mathrm{~b}, \mathrm{c}$ \\
\hline 0 & 0 & $0.0 \pm 0.0$ & 0.0 & $0.3 \pm 0.3 \mathrm{c}$ \\
\hline
\end{tabular}

a) Tested from November 21 to December10, 2005 using three traps for each lure. ${ }^{b)}$ Mean \pm SE. Values within each column followed by a different letter are significantly different at $P<0.05$ by Tukey-Kramer test. ${ }^{c}$ Tested from November 17 to 30,2005 using one trap for each lure. ${ }^{d)}$ Tested from September 8 to 14, 2007 using three traps for each lure. 
Table 3. Attraction of Phylocnistic citrella males by lures baited with synthetic Z7,Z11-16:Ald and Z7,E11,E13-16:Ald in citrus orchards in Vietnam and Japan (Test II)

\begin{tabular}{|c|c|c|c|c|}
\hline \multirow{2}{*}{\multicolumn{2}{|c|}{$\begin{array}{l}\text { Lure components } \\
\text { (mg/rubber septum) }\end{array}$}} & \multicolumn{3}{|c|}{ Captured males/trap/night ${ }^{a)}$} \\
\hline & & \multirow{2}{*}{$\begin{array}{c}\text { Vietnam } \\
\text { Can Tho City }\end{array}$} & \multicolumn{2}{|c|}{ Japan } \\
\hline Z7,Z11-16:Ald & Z7,E11,E13-16:Ald & & Ogasawara Islands ${ }^{c}$ & Matsuyama-shi $^{d)}$ \\
\hline 0.20 & 0 & $0.8 \pm 0.6 \mathrm{~b}$ & $8.9 \pm 1.8 \mathrm{a}$ & $18.2 \pm 2.9 \mathrm{a}$ \\
\hline 0.15 & 0.05 & $0.9 \pm 0.4 \mathrm{~b}$ & $10.3 \pm 0.8 \mathrm{a}$ & $17.4 \pm 2.4 \mathrm{a}$ \\
\hline 0.10 & 0.10 & $1.5 \pm 1.0 \mathrm{~b}$ & $10.4 \pm 0.4 \mathrm{a}$ & $10.9 \pm 1.0 \mathrm{~b}$ \\
\hline 0.05 & 0.15 & $0.6 \pm 0.4 b$ & $5.9 \pm 1.3 \mathrm{a}$ & $3.4 \pm 0.9 \mathrm{c}$ \\
\hline 0 & 0.20 & $1.9 \pm 2.4 \mathrm{~b}$ & $0.6 \pm 0.4 \mathrm{~b}$ & $1.1 \pm 1.1 \mathrm{c}, \mathrm{d}$ \\
\hline 0 & 0 & $0.1 \pm 0.1 \mathrm{~b}$ & $0.3 \pm 0.3 \mathrm{~b}$ & $0.2 \pm 0.2 \mathrm{~d}$ \\
\hline 0.05 & $0.15^{e)}$ & $41.7 \pm 13.7 \mathrm{a}$ & $6.7 \pm 3.3 \mathrm{a}$ & $9.3 \pm 3.9 \mathrm{a}, \mathrm{b}$ \\
\hline
\end{tabular}

${ }^{a)}$ Mean \pm SE. Values within each column followed by a different letter are significantly different at $P<0.05$ by Tukey-Kramer test. ${ }^{b)}$ Tested from January 12 to February 13, 2006 using three traps for each lure. ${ }^{c}$ Tested from January 19 to February 20, 2006 using two traps for each lure. ${ }^{d)}$ Tested from October 18 to 27,2007 using three traps for each lure. ${ }^{e)}$ Z7,Z11,E13-16:Ald.

Z7,Z11,E13-16:Ald. Finally, the effect of the unnatural isomer on the natural-type mixture was examined (Test III). The captured males did not decrease with the addition of Z7,E11,E13-16:Ald even at the same level of the dienal, as shown in Table 4, indicating that pure Z7,Z11,E13-16:Ald was not necessary as the trienyl component.

\section{Field attraction in Japan}

The same field evaluation (Tests I-III) was carried out in citrus orchards in Ogasawara Islands and Matsuyama-shi from 2005 to 2007. To attract the Japanese strain, a lure including only Z7,Z11-16:Ald was sufficient, and the addition of
Z7,Z11,E13-16:Ald was not necessary. The unmixed dienal was the strongest attractant among the tested lures, as shown in Tables 2-4. Far from being reinforced, the attraction activity of the dienal was diminished by mixing with Z7,Z11,E1316:Ald (Table 2). The inhibitory activity of Z7,E11,E1316:Ald was weaker than that of Z7,Z11,E13-16:Ald (Table 3), while neither trienal was secreted by the Japanese strain. In these field tests, no other lepidopteran insects were attracted with synthetic lures.

\section{Discussion}

(7Z,11Z,13E)-7,11,13-Hexadecatrienal (Z7,Z11,E13-16:Ald),

Table 4. Attraction of Phylocnistic citrella males by lures baited with synthetic Z7,Z11-16:Ald, Z7,Z11,E13-16:Ald, and Z7,E11,E1316:Ald in citrus orchards in Vietnam and Japan (Test III)

\begin{tabular}{|c|c|c|c|c|c|}
\hline \multirow{2}{*}{\multicolumn{3}{|c|}{$\begin{array}{l}\text { Lure components } \\
\text { (mg/rubber septum) }\end{array}$}} & \multicolumn{3}{|c|}{ Captured males/trap/night ${ }^{a)}$} \\
\hline & & & \multirow{2}{*}{$\begin{array}{c}\text { Vietnam } \\
\text { Can Tho City }\end{array}$} & \multicolumn{2}{|c|}{ Japan } \\
\hline Z7,Z11-16:Ald & Z7,Z11,E13-16:Ald & Z7,E11,E13-16:Ald & & Ogasawara Islands ${ }^{c}$ & Matsuyama-shi $^{d)}$ \\
\hline 0.20 & 0 & 0 & $0.5 \pm 0.3 \mathrm{c}$ & $16.5 \pm 0.8 \mathrm{a}$ & $11.7 \pm 3.3 \mathrm{a}$ \\
\hline 0.05 & 0.15 & 0 & $18.6 \pm 12.1 \mathrm{a}$ & $12.7 \pm 0.1 \mathrm{a}$ & $5.7 \pm 1.3 \mathrm{~b}$ \\
\hline 0.05 & 0.15 & 0.01 & $21.7 \pm 13.3 \mathrm{a}$ & $9.6 \pm 0.8 \mathrm{a}, \mathrm{b}$ & $8.3 \pm 1.5 \mathrm{a}, \mathrm{b}$ \\
\hline 0.05 & 0.15 & 0.05 & $24.8 \pm 12.5 \mathrm{a}$ & $8.0 \pm 1.4 \mathrm{a}, \mathrm{b}$ & $9.4 \pm 2.3 \mathrm{a}, \mathrm{b}$ \\
\hline 0.05 & 0.15 & 0.15 & $15.5 \pm 9.3 \mathrm{a}, \mathrm{b}$ & $8.1 \pm 2.8 \mathrm{a}, \mathrm{b}$ & $7.1 \pm 2.0 \mathrm{a}, \mathrm{b}$ \\
\hline 0 & 0.15 & 0.05 & $2.1 \pm 1.1 \mathrm{~b}, \mathrm{c}$ & $1.6 \pm 1.3 \mathrm{~b}, \mathrm{c}$ & - \\
\hline 0 & 0 & 0 & $0.1 \pm 0.1 \mathrm{c}$ & $0.3 \pm 0.3 \mathrm{c}$ & $0.0 \pm 0.0$ \\
\hline
\end{tabular}

${ }^{a)}$ Mean \pm SE. Values within each column followed by a different letter are significantly different at $P<0.05$ by Tukey-Kramer test. ${ }^{b)}$ Tested from February14 to March 12, 2006 using three traps for each lure. ${ }^{c}$ Tested from March 16 to April 5, 2006 using two traps for each lure.

d) Tested from September 26 to October 3, 2007 using three traps for each lure. 
which was newly identified from $P$. citrella females inhabiting Brazil and California, ${ }^{3,4}$ has been synthesized via acetylenecoupling and subsequent Wittig-coupling reactions using $\mathrm{C}_{5}$, $\mathrm{C}_{6}$, and $\mathrm{C}_{5}$ building blocks ${ }^{3)}$ or $\mathrm{C}_{8}, \mathrm{C}_{3}$, and $\mathrm{C}_{5}$ building blocks. $\left.{ }^{4}\right)$ We applied another synthetic strategy, namely, two applications of the Wittig-coupling reaction using $\mathrm{C}_{7}, \mathrm{C}_{4}$, and $\mathrm{C}_{5}$ building blocks. In addition to Z7,Z11,E13-16:Ald, the $(7 Z, 11 E, 13 E)$-isomer was produced by our synthetic route (Fig. 1). Since the geometrical isomers contain different configurations at the conjugated dienyl part, their separation with an $\mathrm{AgNO}_{3}$-silica gel column was difficult. HPLC equipped with an ODS column, however, accomplished the separation in a similar manner to that for conjugated dienyl compounds. ${ }^{10)}$ Configuration of the separated trienyl compounds was confirmed by NMR analyses. In particular, their ${ }^{13} \mathrm{C}$ NMR data (Table 1) are informative because most of the signals were recorded without overlapping.

Field tests of the trienals mixed with $(7 Z, 11 Z)-7,11$-hexadecadienal (Z7,Z11-16:Ald), which has been universally identified from females of each strain, including the Japanese strain, ${ }^{1)}$ successfully characterized two Asian strains of $P$. citrella. The results of the male attraction (Tables 2-4) indicated that the sex pheromone of the Vietnamese strain might be similar to that of strains in the Americas, i.e., a 1:3 mixture of Z7,Z11-16:Ald and Z7,Z11,E13-16:Ald; however, the Japanese strain, which secretes only Z7,Z11-16:Ald, established a different communication system from those of foreign strains. This indicates the risk of further infection by a new strain in citrus orchards in Japan in the future; thus, it is worthwhile to monitor the entrance of foreign strains into Japan by pheromone traps. Moreover, genetic characterization of the insect is also important to clarify whether the Japanese citrus leafminer is a subspecies or a different species of an overseas strain.

\section{Acknowledgments}

The authors are grateful to Drs. F. Mochizuki and T. Fukumoto of Shin-etsu Chemical Co., Ltd. for supplying (7Z,11Z)-7,11-hexadecadienyl acetate.

\section{References}

1) T. Ando, K. Taguchi, M. Uchiyama, T. Ujiye and H. Kuroko: Agric. Biol. Chem. 49, 3633-3635 (1985).

2) S. A. Mafi, L. V. Vang, Y. Nakata, N. Ohbayashi, M. Yamamoto and T. Ando: J. Pestic. Sci. 30, 361-367 (2005).

3) W. S. Leal, A. L. Parra-Pedrazzoli, A. A. Cossé, Y. Murata, J. M. S. Bento and E. F. Vilela: J. Chem. Ecol. 32, 155-168 (2006).

4) J. A. Moreira, J. S. McElfresh and J. G. Millar: J. Chem. Ecol. 32, 169-194 (2006).

5) T. Ando, S. Inomata and M. Yamamoto: Topics Curr. Chem. 239, 51-96 (2004).

6) http://www.tuat.ac.jp/ antetsu/LepiPheroList.htm.

7) Z. Xu, H.-S. Byun and R. Bittman: J. Org. Chem. 56, 7183$7186(1991)$.

8) T. Ando, K. Kusa, M. Uchiyama, S. Yoshida and N. Takahashi: Agric. Biol. Chem. 47, 2849-2853 (1983).

9) T. Ando, Y. Kurotsu, M. Kaiya and M. Uchiyama: Agric. Biol. Chem. 49, 141-148 (1985)

10) T. Nishida, L. V. Vang, H. Yamazawa, R. Yoshida, H. Naka, K. Tsuchida and T. Ando: Biosci. Biotechnol. Biochem. 67, 822829 (2003). 